\title{
Passive avoidance during brain-growth spurts and plateaus
}

\author{
MARIA J. LAVOOY \\ Miami University, Oxford, Ohio 45056 \\ JACQUELINE LAVOOY and MARTIN E. HAHN \\ William Paterson College, Wayne, New Jersey 07470 \\ and \\ EDWARD C. SIMMEL \\ Miami University, Oxford, Ohio 45056
}

\begin{abstract}
Epstein has suggested that normal brain development is characterized by spurts and plateaus. In mice, these spurts seem to appear at $0-6,8-12$ or 13 , and 17-23 days, and plateaus appear at 6-8, 12-17, and after 23 days of age. Results have demonstrated enhanced learning in a spurt (11 and 19 days of age) and a decrement in learning at a plateau (15 days of age), using an active avoidance task to measure learning in Fuller BWS high and low brain-weight lines. We tested Fuller BWS high- and low-line mice in a passive avoidance task at 11, 15, and 19 days of age. Mice were also tested at 12 days of age, since a recent study found that 12-day-old mice are in a plateau rather than a spurt, as previously reported. As high activity levels may conflict with the response made, activity levels were also measured on the day of testing. The results revealed an age effect and an Age by Line interaction, but no line effect: Mice at 11 and 19 days of age (spurts) differed significantly from mice 15 and 12 days of age (plateaus). Activity was not found to be a confounding measure.
\end{abstract}

Recent work has shown that brain size can be influenced by variables such as nutrition, environment, maternal behavior, and genes (Hahn, Jensen, \& Dudek, 1979). It also appears that brain size is related to behavior, as species with larger average brain size in relation to average body size show greater ability to process and utilize information.

Epstein (1979) has shown a stagewise growth in average brain weight, and he correlates these braingrowth stages with mind-growth stages, or Piaget's stages of intellectual development. He suggests that the normal course of human brain development is not a linear process but, rather, is characterized by specific stages of rapid and slow growth, or spurts and plateaus, respectively.

A study by Gottlieb, Keydar, and Epstein (1977) on mouse and rat brain growth from birth to weaning shows rapid growth (spurts) at $0-6,8-12$ or 13 , and 17-23 days, and slow growth (plateaus) at 6-8, 12-17, and after 23 days of age.

Epstein's (1979) work predicts a decrement in learning ability at a plateau and increased learning in a spurt. This hypothesis was tested, with mice, by DeLuca, Bischoff, Kelman, Lavooy, Phillips, Posch, Wolf, and

Requests for reprints should be addressed to Maria J. Lavooy, Behavior Genetics Laboratory, Psychology Department, Miami University, Oxford, Ohio 45056.
Hahn (Note 1), in a shock-escape T-maze. They found that learning occurred in all groups tested, that age affects learning, and that age affects learning differentially during the brain-growth stages. Mice at age 11 days and mice at age 15 days did not differ in performance. However, mice at age 19 days were superior in performance to both 11- and 15-day-olds. These results have been interpreted as a demonstration of enhanced learning at a period of increased brain growth, or spurt, and a decrement in learning at a plateau. The same age effects occurred in both the high brain-weight and low brainweight lines.

Recent work has also shown that mice are capable of learning a passive avoidance response when they are as young as 7 days of age (Ray \& Nagy, 1978). The passive avoidance situation is markedly different, however, from the shock-avoidance situation. In an active avoidance situation, the shock is not turned off until the animal has made the correct response. In passive avoidance, on the other hand, the subject is required to refrain from making some designated response; it avoids shock by not doing something. The passive avoidance situation requires that the animal remain on the disk; that is, the animal must withhold or inhibit a response. As high activity levels may conflict with the number of responses made, results obtained with a shock avoidance maze may not be entirely indicative of the general ability of an animal to learn the maze. Riccio and Schulenberg 
(1969) have suggested that 15-day-old mice are poor learners because they are too active at this age. At any rate, the use of more than one learning task may serve to strengthen the demonstrated relationship between learning ability and brain-growth spurts and plateaus.

A recent study by Hahn, Walters, and DeLuca (Note 2) found that 12-day-old animals are in a plateau rather than a spurt, as previously reported by Gottlieb et al. (1977). We tested mice in a passive avoidance situation at 11,15 , and 19 days of age, since 11- and 19-day-old animals are in established spurts and 15-day-old animals are in an established plateau. Mice were tested at 12 days of age to attempt to determine whether the performance of these mice would show any relationship to previously suggested spurts and plateaus. Activity levels were also measured, prior to passive avoidance testing, for all mice.

\section{METHOD}

\section{Subjects}

Forty-eight litters (315 mice) of the Fuller Brain Weight Selection (BWS) high and low brain-weight lines were used in this study. The Fuller lines were genetically selected for differential brain size; they include a high line $(\mathrm{H})$, a low line (L), and a medium line (M) (Fuller \& Herman, 1974). The $\mathrm{H}$ and $\mathrm{L}$ lines were chosen for this experiment because they exhibit differential rates of neural and behavioral development (Fuller \& Herman, 1974; Hahn, 1979).

All of the mice were bred and housed in the William Paterson College Animal Behavior Laboratory. Breeding pairs were formed from Generation 27, and the subjects were from Generation 28. All breeding pairs and their litters were maintained in Lab Products Polycarbonate cages with Stayz-Dri bedding and one cotton Nestlet for nest building. Charles River Mouse Chow and water were available ad lib through a stainless steel cage top, and all cages were cleaned weekly. The temperature of the room was maintained at approximately $21^{\circ} \mathrm{C}$ on a standard $12 \mathrm{~h}$ light $/ 12 \mathrm{~h}$ dark cycle. Cages were checked daily between 11:00 a.m. and 1:00 p.m., and all litters were culled to eight pups. Litters with fewer than four pups were not used. All subjects remained in their home cages with their littermates and both parents until testing began.

\section{Apparatus}

The test apparatus consisted of a small elevated platform on a grid, similar to the apparatus used by Ray and Nagy (1978). The platforms were constructed of 3-mm clear Plexiglas, which measured $40 \mathrm{~cm}$ around, $50 \mathrm{~cm}$ around, and $55 \mathrm{~cm}$ around, for 11- and 12-day-old mice, 15-day-old mice, and 19-day-old mice, respectively. The platform sat $6 \mathrm{~mm}$ off of a parallel grid consisting of $2-\mathrm{mm}$ steel rods and was surrounded by a Plexiglas case measuring $25 \times 15 \mathrm{~mm}$. The steel rods were held in place by Plexiglas end pieces, and each bar was wired separately to a scrambler shock source that delivered $.22 \mathrm{~mA}$ of current.

\section{Procedure}

Activity. To measure activity, the pups were placed in an open-field apparatus, one at a time, for $60 \mathrm{sec}$, and the number of squares entered with all four paws was recorded. Following this test, the mouse was given an identification mark, with black magic marker, on one, two, or three paws and was placed in a holding cage. When all pups in the litter had been tested for activity, they were returned to their home cages. Testing was completed between 9:30 and 11:00 a.m. on the day the litter was scheduled to be tested for passive avoidance.
Learning. At the beginning of the learning procedure, a mouse was removed from its home cage and was placed in the apparatus, with all four paws on the platform. The clock was started and the mouse was required to stay on the elevated platform to avoid shock administered through the grid. A trial ended when the mouse either stepped off the platform with all four feet on the grid or remained on the platform for $120 \mathrm{sec}$. The mouse was then placed in a holding cage for $30 \mathrm{sec}$. Testing continued for each mouse until 15 trials were completed or until the mouse had remained on the platform for two consecutive 120 -sec trials, providing that at least one step-off response had been made. Testing began at 11:00 a.m. each day.

\section{RESULTS}

The performance data were analyzed by a 2 by 4 analysis of variance with line $(\mathrm{H}$ and $\mathrm{L})$ and age (11, 12,15 , and 19 days) as factors. The measures included activity, the number of trials to criterion, and the percent litter to criterion (see Table 1). The analysis of variance revealed an age effect, no line effect, and an Age by Line interaction.

The activity measure revealed an Age by Line interaction $(\mathrm{p}<.001)$. A one-way analysis of variance for $\mathrm{H}$ and $\mathrm{L}$ lines indicated no significant differences among the means measured for activity for all ages $[F(3,20)=$ 2.58 , and $F(3,20)=1.80$, for $\mathrm{N}$ and $\mathrm{L}$ lines, respectively] . A Duncan multiple-range test showed that the $\mathrm{H}$ line 11-day-old mice differed significantly from 19-day-old mice, but no significant difference existed between any of the other days, including 12 days compared with 19,15 with 19,12 with 15,11 with 12 , and 11 with 15 . No significant differences existed among the 4 days tested for the $\mathrm{L}$ line.

There was an age by line interaction $(p<.001)$ for the trials-to-criterion measure. A one-way analysis of variance indicated that the $\mathrm{H}$ line was significant $[F(3,20)=7.04, p<.005]$ and the $L$ line was significant $[F(3,20)=15.96, p<.001]$. A Duncan multiplerange test revealed that, for the $\mathrm{H}$ line, 11 differed from 12 and 15 days, but not from 19 days, and none of the other days differed from each other. Nineteen was signif-

Table 1

Means and Standard Errors of Performance Measures by Age (in Days)

\begin{tabular}{|c|c|c|c|c|c|c|}
\hline \multirow[b]{2}{*}{ Age } & \multicolumn{2}{|c|}{ Activity } & \multicolumn{2}{|c|}{$\begin{array}{l}\text { Trials to } \\
\text { Criterion }\end{array}$} & \multicolumn{2}{|c|}{$\begin{array}{l}\text { Percent Litter to } \\
\text { Criterion }\end{array}$} \\
\hline & Mean & $\mathrm{SE}$ & Mean & SE & Mean & SE \\
\hline \multicolumn{7}{|c|}{ High Line } \\
\hline $\begin{array}{l}11 \\
12 \\
15 \\
19\end{array}$ & $\begin{array}{r}7.9 \\
11.4 \\
13.5 \\
19.0\end{array}$ & $\begin{array}{l}1.43 \\
1.39 \\
4.82 \\
2.53\end{array}$ & $\begin{array}{l}10.0 \\
14.4 \\
14.6 \\
12.8\end{array}$ & $\begin{array}{r}1.35 \\
.41 \\
.25 \\
.74\end{array}$ & $\begin{array}{r}58.9 \\
18.8 \\
6.3 \\
44.4\end{array}$ & $\begin{array}{r}13.35 \\
11.96 \\
4.29 \\
12.45\end{array}$ \\
\hline \multicolumn{7}{|c|}{ Low Line } \\
\hline $\begin{array}{l}11 \\
12 \\
15 \\
19\end{array}$ & $\begin{array}{l}13.0 \\
12.4 \\
22.6 \\
20.4\end{array}$ & $\begin{array}{l}2.04 \\
2.37 \\
3.55 \\
6.12\end{array}$ & $\begin{array}{l}13.3 \\
13.0 \\
14.3 \\
10.0\end{array}$ & $\begin{array}{l}.53 \\
.37 \\
.33 \\
.61\end{array}$ & $\begin{array}{l}37.0 \\
36.1 \\
22.2 \\
80.0\end{array}$ & $\begin{array}{r}14.86 \\
7.51 \\
9.84 \\
11.43\end{array}$ \\
\hline
\end{tabular}


icantly different from 11,12 , and 15 days in the $\mathrm{L}$ line, but no other days were significantly different from each other.

The percent litter to criterion measure indicated an Age by Line interaction $(p<.025)$, and a one-way analysis of variance showed that the $\mathrm{H}$ line was significant $[F(3,20)=4.63, p<.025]$ and the $L$ line was significant $[F(3,20)=4.98, p<.01]$. A Duncan multiple-range test revealed that, for the $\mathrm{H}$ line, 11 -dayold animals were significantly different from both 12 and 15-day-old animals, but not from 19-day-old animals, and 19-day-old animals were significantly different from 15-day-old animals. The 19-day-old animals were significantly different from 11-, 12-, and 15-day-old animals in the $\mathrm{L}$ line, but no other days were significantly different from each other.

Activity was not found to correlate with either trials to criterion $(r=.1229, \mathrm{H}$ line; $\mathrm{r}=.0638, \mathrm{~L}$ line $)$ or percent litter to criterion $(r=.1789, \mathrm{H}$ line; $\mathrm{r}=.0316$, L line).

\section{Discussion}

Our results show that the Fuller BWS mice differ in their ability to learn a passive avoidance task. There was an age effect and an Age by Line interaction, but no line effect. Mice at 11 days (second spurt) and 19 days (third spurt) of age differed significantly from mice 15 days of age (second plateau), as hypothesized by Gottlieb et al. (1979), and they differed from mice 12 days old as well, as hypothesized by Hahn et al. (Note 2).

Riccio and Schulenberg (1969) suggested that 15-day-old mice do not learn as well as mice of other ages because their activity levels are too high, yet we found no evidence of higher activity levels at 15 days of age, and DeLuca et al. (Note 1) found that 19-day-old mice gave significantly more competing responses than mice of any other age, including 15-day-old animals. The activity levels in this study did not single out 15-day-old mice as any more or less active than mice of any other age.

As indicated by Ray and Nagy (1978) and Riccio and Schulenberg (1969), 11-day-old mice performed better than 15-day-old mice, although Riccio and Schulenberg found that 15-day-old mice never learned; this is not in agreement with the findings of this study, as some 15-day-old mice did learn.

Although there was no line effect for any of the measures we used, the absence of such an effect is consistent with the work of Herman and Nagy (1977), Jensen (1979), and Deluca et al. (Note 1), suggesting that brain size and learning are not consistently related in the Fuller BWS mice.

These results are interpreted as a demonstration of enhanced learning during a period of increased brain growth (a spurt), which includes 11- and 19-day-old mice, and a decrement in learning during minimal brain growth (a plateau), which includes 15-day-old mice. It would also appear from these data that 12-day-old BWS mice are actually at a plateau, as suggested by the data of Hahn et al. (Note 2), and are not in a spurt, as suggested by Gottlieb et al. (1977).

We suggest that these findings support the hypothesis that 11- and 19-day-old BWS mice are in a brain-growth spurt and that 12- and 15-day-old BWS mice are at a brain-growth plateau. It also appears that activity is not a confounding measure in the ability of these mice to learn a passive avoidance task.

\section{REFERENCE NOTES}

1. DeLuca, J., Bischoff, H., Kelman, S., Lavooy, M. J., Phillips, T., Posch, R., Wolf, P., \& Hahn, M. E. Effects of genes and handling on learning during brain growth spurts and plateaus. Paper presented at the meeting of the International Society for Developmental Psychobiology, Atlanta, Georgia, November 1979.

2. Hahn, M. E., Walters, J. K., \& DeLuca, J. Brain weight development in the Fuller $B W S$ lines and the heterogeneous population. Paper presented at the Symposium on Cognitive Development in the Young: Implications for the Curriculum, Wayne, New Jersey, April 26, 1980.

\section{REFERENCES}

Epste in, H. T. Correlated brain and intelligence development in humans. In M. E. Hahn, C. Jensen, \& B. C. Dudek (Eds.) Development and evolution of brain size: Behavioral implications. New York: Academic Press, 1979.

Fuller, J. L., \& Herman, B. H. Effect of genotype and practice upon behavioral development in mice. Developmental Psychobiology, 1974, 7, 21-30.

Gottlieb, A., Keydar, I., \& Epstein, H. T. Rodent brain growth spurts: An analytical review. Biology of the Neonate, 1977, 32, 166-176.

HAHN, M. E. Fuller BWS lines: Parental influences on brain size and development. In M. E. Hahn, C. Jensen, \& B. C. Dudek (Eds.), Development and evolution of brain size: Behavioral implications. New York: Academic Press, 1979.

Hahn, M. E., Jensen, C., \& Dude K, B. C. (Eds.). Development and evolution of brain size: Behavioral implications. New York: Academic Press, 1979.

Herman, B. H., \& Nagy, Z. M. Development of learning and memory in mice genetically selected for differences in brain weight. Developmental Psychobiology, 1977, 10, 65-75.

JENSEN, C. Learning performance in mice genetically selected for brain weight: Problems of generality. In M. E. Hahn, C. Jensen, \& B. C. Dudek (Eds.), Development and evolution of brain size: Behavioral implications. New York: Academic Press, 1979.

RAY, D., \& NAGY, Z. M. Emerging cholinergic mechanisms and the ontogeny of response inhibition in the mouse. Journal of Comparative and Physiological Psychology, 1978, 92, 335-349.

Riccio, D. C., \& Schulenberg, C. J. Age-related deficits in acquisition of a passive avoidance response. Canadian Journal of Psychology, 1969, 23, 429-437.

(Received for publication February 26, 1981.) 